\title{
MINIMUM UNIT PRICING IN SCOTCH WHISKY ASSOCIATION V LORD ADVOCATE
}

\section{Angus MacCulloch*}

Five years after the Scottish Government first introduced the Bill that went on to become the Alcohol Pricing (Minimum Pricing)(Scotland) Act 2012 the legal challenge to the implementation of the legislation was back before the Inner House of the Court of Session for its final consideration by the Scottish courts. ${ }^{1}$ Lord Carloway, the Lord President, delivered the court's judgment refusing the reclaiming motion and confirming that, following the preliminary ruling from the Court of Justice (CJEU), ${ }^{2}$ the Lord Ordinary had correctly applied EU law and found that Minimum Unit Pricing (MUP) was not contrary to Art 34 TFEU as it was an appropriate and necessary measure to protect public health.

\section{A. THE JUDGMENT}

The central question in the appeal was whether the Lord Ordinary had applied the correct test in assessing the public health justification of the measure under Art 36 TFEU. The test, as set out by the CJEU in its ruling, was that the measure must have been appropriate to secure the public health objective, and must not go beyond what was necessary to attain it. Before addressing the test itself it was important that the Inner House clearly delineated the aim of the legislation. This had become an important question before the CJEU, where the Advocate General had identified "ambiguity" as to the aim $^{3}$ and the CJEU found the measure to have a "twofold objective", 4 viewing reduction in general consumption and dealing with consumption by harmful and hazardous drinkers as two separate objectives. Neither the Lord Ordinary nor the Lord President struggled with any such ambiguity; the aim of the measure was considered to be "to reduce alcohol consumption generally, and in particular that of harmful drinkers". There is duality in that formulation, but the primary focus on the "targeted objective" of alcohol misuse and overconsumption stemming from cheap alcohol is clear throughout the judgment. ${ }^{5}$

When the Inner House turned to consider the appropriateness of the measure the court stressed that it was for the state to exercise a margin of discretion and decide on the degree of protection that it wished to adopt. In doing so it should consider the extent of the particular problem within that jurisdiction. The court noted that the "societal, family and personal effects of excessive alcohol consumption in Scotland are difficult to overestimate". ${ }^{6}$ It was also noted that there was an acute problem in less affluent communities, which also suffer from more severe alcohol related health problems. Harmful and hazardous drinkers tend to consume cheap alcohol, and therefore will be more affected by the measure when compared to more affluent drinkers, as they cannot "trade down" to cheaper products. The Lord Ordinary had found that the major problem in Scotland was the

\footnotetext{
* Lancaster University Law School

${ }^{1}$ The Scotch Whisky Assoc \& Others v LA [2016] CSIH 77. N.b., leave to appeal to the Supreme Court has been granted.

${ }^{2}$ Case C-333/14 SWA v LA ECLI:EU:C:2015:845. See A Alemanno, 'Balancing free movement and public health: the case of minimum unit pricing of alcohol in Scotch Whisky' (2016) 53(4) CMLRev 1037 \& O Bartlett, 'Minimum unit pricing for alcohol may not be a proportionate public health intervention' [2016] EJRR 218.

${ }^{3}$ AG Bot, SWA ECLI:EU:C:2015:527, 117-118.

${ }^{4}$ SWA, n 2, 34.

${ }^{5}$ See, for example, SWA, n 1, 185.

6 Ibid, 178.
} 
excessive consumption of cheap alcohol. The court could find no fault in that: MUP was "an appropriate method of securing the objective by tackling the specific consumption of cheap alcohol". 7

Once it was decided that the Lord Ordinary had been correct to identify that MUP was an appropriate means of targeting the consumption of cheap alcohol the court turned its attention to the proportionality of the measure, and in particular whether a less restrictive measure could achieve the same, or a similar, objective. It was stressed that the state must use appropriate evidence to demonstrate the proportionality of the measure, but it did not have to prove that no other measure could achieve the objective. ${ }^{8}$ The task of the court was:

to compare the effectiveness of minimum unit pricing in achieving the targeted objective, with other measures which could also achieve that objective, and which would be less restrictive of intra-EU trade. Only if minimum pricing is the more effective way of achieving the objective will the interference with the market be necessary and therefore proportionate under Article $36 .{ }^{9}$

It was also stressed that the inherently experimental nature of the introduction of a new measure could be managed within that analysis. The question in this case was whether raising the general level of taxation on alcohol could achieve the objective, or be "as effective", with less impact on trade. After rehearsing the Lord Ordinary's analysis the judgment, in arguably its most important passage, set out:

The fundamental problem with an increase in tax is simply that it does not produce a minimum price. As stated in the Memorandum, many supermarkets have, in the past, sold alcohol at below cost. They have absorbed any tax increases by off-setting them against the price of other products unrelated to alcohol. ${ }^{10}$

The advantage of minimum pricing is the direct link between price and the alcoholic strength of the products sold. Given the structure of UK and EU tax arrangements it is impossible for tax increases to make this direct linkage. Taxation on cider, for instance, does not allow for variation in taxation according to strength - and given that strong white ciders are seen as one of the most problematic products for harmful and dependant drinkers this is a particular concern. The court relied on evidence that MUP would target the products consumed by harmful and hazardous drinkers as that group tended to purchase cheap alcohol, explaining that:

price increases targeted at the lowest cost brands would produce a greater reduction in sales than across the board price increases. This is because trading down is not possible where the alcohol is at its minimum price. ... This targeting cannot be achieved by a tax increase directed at low cost products, because EU law will not permit there to be anything other than a uniform rate. ${ }^{11}$

On that basis the court was convinced that the Lord Ordinary's conclusion that an increase in taxation could never be "as effective" as MUP was supported by the evidence available to

\footnotetext{
${ }^{7}$ Ibid, 183.

8 Ibid, 188.

9 Ibid, 190.

10 lbid, 196.

11 Ibid, 199.
} 
it. In fact the court expressed the view that an "across the board" increase in taxation would have, "a disproportionate, undesirable and unnecessary effect on moderate drinkers". ${ }^{12}$ Although it was not pertinent to its final analysis the court did acknowledge a "curious anomaly" in the case that the Scottish Government, which has responsibility for public health in Scotland, has no power under the devolution settlement to raise taxes, but the UK Government, which can raise taxes, has no responsibility for public health in Scotland. ${ }^{13}$

The nature and timing of the assessment of the evidence as to the proportionality of the measure became an important feature of the case after the Inner House raised them as questions for the CJEU in its preliminary reference. The burden of proof set by the CJEU was seen as being quite onerous. The Inner House should "examine objectively" if it may "reasonably be concluded from the evidence" that the measure's objectives could possibly be attained by measures that are less restrictive of the free movement of goods. ${ }^{14}$ Alemanno suggested that to satisfy that test the Inner House would not merely have to show that MUP was equally effective as taxation, but to show that it could provide more than taxation offered. ${ }^{15}$ The nature of the burden was somewhat ameliorated when the CJEU also accepted that there would be a certain level of scientific uncertainty as to the specific effects of the measure in Scotland; ${ }^{16}$ as it had not yet been introduced. As to the correct time frame for the assessment, the CJEU made it clear that EU law must be complied with at all times, not simply when a measure is introduced but also when it is implemented, and therefore compatibility should be assessed the date the court gives its ruling. ${ }^{17}$ Both of these issues were considered by the Inner House. The pre-legislative history of what was to become the 2012 Act, going as far back as 2007, including the final Business and Regulatory Impact Assessment (BRIA) and various research studies that were relied on by the Scottish Government were considered. ${ }^{18}$ The court also considered new material available after the enactment of the Act. The Petitioners had argued that there should be a "cut off" date for submissions in relation the reclaiming motion prior to the appeal hearing in December 2013. The court did not accept that restriction. In the context of a reclaiming motion the court decided that it was able to accept new material if it demonstrated a change in circumstance. The final decision on this matter was that:

Having regard to the time which has expired between the Lord Ordinary's interlocutor and the final hearing of the reclaiming motion, it is in the interests of justice that any new material, which is pertinent to the issues of Scotland's alcohol consumption and the effect which minimum pricing may have on it and intra-EU trade, should be considered. ... [I]t must be in the interests of justice to look at any additional material which effectively amounts to an update or revision of that material or was information requested, or taken into account, by the CJEU. ${ }^{19}$

The arguments of the respondents relied heavily on the latest evidence from 2013 onwards, as well as the earlier material in the BRIA, and the usefulness of that evidence was

\footnotetext{
12 Ibid, 200.

13 Ibid, 192.

${ }^{14}$ SWA, n 2, 56.

${ }^{15}$ Alemanno, n 2, 1059.

${ }^{16}$ SWA, n 2, 57.

17 Ibid, 62-63.

${ }^{18}$ SWA, n 1, 9-33.

19 Ibid, 110.
} 
challenged by the petitioners. The new material was not separately considered in the court's final decision on the matter, but at several points throughout the judgment the court stressed the nature of the evidence that was presented: there was "ample objective material to support the proposition", ${ }^{20}$ and that "there is material ("evidence") which demonstrates the alternative ... is less effective". ${ }^{21}$ It also discussed the petitioner's challenges to aspects of that evidence:

it is of course almost inevitable that there will be evidence pointing to a different conclusion. However, as the CJEU has ruled, the state does not have to demonstrate that no other conceivable measure could enable the objective to be attained. ${ }^{22}$

\section{B. COMMENT}

The judgment of the Inner House may have come as something of a surprise after the tenor of the CJEU's preliminary ruling, which was perceived as giving some encouragement to the petitioners. The key step in the reasoning in the Inner House, as it was in the Outer House, ${ }^{23}$ was the determination of the aim of the measure. The argument of the Scottish Government as presented in the BRIA, which was the focus of the discussion in the CJEU, was not as clear as it might have been. The introduction of MUP was part of a larger programme of some 40 measures to tackle Scotland's considerable issues with alcohol. Much of the material in the BRIA was therefore quite general in nature. This lack of specification in the aim of MUP led to the concerns about "ambiguity" and its "two-fold objective" as discussed in the CJEU. The weight of the evidence presented by the Lord Advocate, both before the Outer House and latterly before the Inner House, was much clearer as to the efficacy of MUP in dealing with a particular form of problematic alcohol consumption; the consumption of cheap alcohol by harmful and hazardous drinkers. The focus on "cheap alcohol" in particular comes through most strongly in the Inner House's judgment. The lesson to take away is one of clarity. If the aim of the measure is specific, and set out in unambiguous terms, it frames the following proportionality argument. A very general aim could be addressed through several potential measures - of those "effective" measures only the least restrictive to trade will survive the proportionality test. A very specific aim, which is addressed directly by the measure, is far less susceptible to challenge.

The second important point is the role of evidence in the court's deliberations. The court's summary of the evidence presented by the Scottish Government alone runs from paragraphs 125-143 of the judgment. This was described by the court as a "raft of statistical material". ${ }^{24}$ As with any body of evidence which examines different aspects of a problem and is drawn from several sources it was possible to draw different conclusions; the petitioners certainly challenged some aspects of that evidence base (paragraphs 149-165). The CJEU has recently reiterated the importance of the use of good supporting evidence for health justifications in Deutsche Parkinson Vereinigung. ${ }^{25}$ In the MUP case there can be no doubt that the evidence was fully aired both by the parties and by the Inner House before

\footnotetext{
${ }^{20}$ Ibid, 182.

${ }^{21}$ Ibid, 200.

22 Ibid, 205.

${ }^{23}$ See A MacCulloch, 'Minimum alcohol pricing in Scotch Whisky Association v Lord Advocate' (2015) 19(1) Edinburgh LR 106.

${ }^{24}$ SWA, n 1, 180.

${ }^{25}$ Case C-148/15 Deutsche Parkinson Vereinigung eV v Zentrale zur Bekämpfung unlauteren Wettbewerbs eV ECLI:EU:C:2016:776.
} 
adopting it final judgment. The timing of the assessment of the evidence was also a matter of debate, with the court accepting new evidence up until the final hearing. This is significant as it means, following the ruling of the CJEU, that there is no single point in time at which a measure is determined to be, or not be, proportionate. In the context of the MUP legislation it meant that the current state of evidence as to the efficacy of MUP and the problems of Scottish consumption were relevant now, but evidential developments will also continue to be relevant after MUP is introduced. To that end the Scottish Government pointed to the sunset clause in the Act, which means that the legislation would lapse after six years unless it was renewed, as mitigation against any scientific uncertainty in the current evidence ${ }^{26}$ If at some point in the future there is a significant shift in the evidence base that shows that the introduction of MUP is not achieving its objectives its proportionality will once again be in doubt.

${ }^{26}$ SWA, n 1, $129 \& 138$. 